\title{
KEMAMPUAN BERPIKIR KREATIF DALAM MENULIS NARATIF SISWA KELAS V SEKOLAH DASAR NEGERI DI KECAMATAN GAYUNGAN SURABAYA
}

\author{
Lulu Anggi Rhosalia ${ }^{1}$, Kisyani Laksono ${ }^{2}$, Wahyu Sukartiningsih ${ }^{3}$ \\ Pendidikan Dasar, Pascasarjana Universitas Negeri Surabaya \\ email: luluanggie@gmail.com
}

\begin{abstract}
Abstrak
Tujuan umum penelitian ini adalah mendeskripsikan kemampuan berpikir kreatif dalam menulis naratif siswa kelas V sekolah dasar negeri di Kecamatan Gayungan Surabaya. Adapun tujuan khusus penelitian ini adalah mendeskripsikan kelancaran berpikir dalam menulis naratif siswa, mendeskripsikan keluwesan berpikir dalam menulis naratif siswa, dan mendeskripsikan keaslian berpikir dalam menulis naratif siswa. Hasil penelitian menunjukkan bahwa 54 dari 97 siswa kelas V SDN di Kecamatan Gayungan Surabaya yang dijadikan sampel penelitian sudah dapat dinyatakan memiliki kemampuan berpikir kreatif dalam menulis naratif. Secara rinci ada 6\% atau 6 siswa dikategorikan sangat kreatif, $51 \%$ atau 49 siswa dikategorikan kreatif, $4 \%$ atau 4 siswa dikategorikan cukup kreatif, 26\% atau 25 siswa dikategorikan kurang kreatif, dan $13 \%$ atau 13 siswa dikategorikan tidak kreatif.Tingkat kemampuan berpikir kreatif dalam menulis naratif tersebut ditentukan oleh tiga indikator yang meliputi kelancaran, keluwesan, dan keaslian. Secara rinci 81 dari 97 siswa sudah memenuhi indikator kelancaran berpikir dalam menulis naratif. Ada 56 siswa yang dapat dinyatakan memenuhi indikator keluwesan berpikir dalam menulis naratif. Hanya ada 6 siswa yang dapat dinyatakan memenuhi indikator keaslian.
\end{abstract}

Kata Kunci: Kemampuan Berpikir Kreatif, Menulis Naratif, Kelancaran, Keluwesan, Keaslian.

\begin{abstract}
The general purpose of this research is to describe the creative thinking ability in writing narrative fifth grade students of state elementary schools in District Gayungan Surabaya. The specific purpose of this study is to describe the fluency think in narrative writing student, described the flexibility of thinking in students 'writing narrative and describe the originality of students' thinking in writing narrative.This research is descriptive research with quantitative approach. Researchers used a sample of 97 students from three different schools, namely SDN Ketintang I / 409 Surabaya, SDN Gayungan II / 423 Surabaya, and SDN Dukuh Menanggal I / 424 Surabaya. Research procedure includes the preparation stage, the stage of collecting data, and analyzing data. The research data is the results of narrative writing test. The data collection techniques performed through engineering tests and questionnaires. The data analyzed by quantitative descriptive technique.The results of this study showed that 54 of 97 students of class V SDN in District Gayungan Surabaya sampled study can already be declared to have the ability to think creatively in narrative writing. In detail, there are 6\% or 6 students categorized as very creative, $45 \%$ or 44 students categorized as creative, $4 \%$ or 4 students categorized quite creative, $21 \%$ or 20 students categorized as less creative, and a $13 \%$ or 13 students categorized as not creative. Level of creative thinking ability in narrative writing is determined by three indicators that include fluency, flexibility and originality. In detail, 81 of 97 students already meet the indicators of fluency think in narrative writing. There are 55 students who could otherwise meet the indicators of flexibility to think in narrative writing. There are only 6 students who could otherwise meet the indicator of originality in narrative writing.
\end{abstract}

Keywords: Creative Thinking Ability, Writing Narrative, Fluency, Flexibility, Originality

\section{PENDAHULUAN}

Kemampuan berpikir kreatif dapat dikembangkan melalui pendidikan. Pernyataan ini sesuai dengan rumusan dalam Undang-undang nomor 20 tentang Sistem Pendidikan Nasional Tahun 2003 menyatakan bahwa pendidikan nasional bertujuan untuk berkembangnya potensi siswa agar menjadi manusia yang beriman dan bertakwa kepada Tuhan Yang Maha Esa, berakhlak mulia, dan berkepribadian luhur; berilmu, cakap, kritis, kreatif, dan inovatif; sehat, mandiri, dan percaya diri; dan toleran, peka sosial, demokratis, dan bertanggung jawab.

Pernyataan tersebut menunjukkan bahwa tujuan pendidikan bukan sekadar menciptakan lulusan yang memiliki predikat tamat belajar semata, tetapi lebih dari itu yaitu menciptakan lulusan yang berkualitas. Lulusan yang berkualitas ini diharapkan mampu memecahkan berbagai masalah baik bagi dirinya sendiri, maupun bagi 
lingkungan sekitarnya. Kemampuan yang demikian akan dimungkinkan jika lulusan pendidikan tersebut memiliki kreativitas.

Kreativitas, menurut Akhadiah dkk. (1993:13) pada hakikatnya merupakan perwujudan dari kemampuan berpikir kreatif. Dengan mewujudkan kemampuan berpikir kreatifnya, siswa dapat mengaktualisasikan dirinya. Aktualisasi diri ini merupakan kebutuhan pokok pada tingkat tertinggi dalam hidup manusia (Maslow, dalam Munandar,1999:31). Di samping itu, kemampuan berpikir kreatif merupakan kunci meraih keberhasilan dalam memecahkan masalah, karena kreativitaslah yang menjembatani antara tahap pengelolaan kognisi terhadap tahap eksekusi agar seseorang memiliki prestasi atau hasil yang meyakinkan (Sunito dkk., 2013:12). Sementara itu, pada era globalisasi seperti saat ini semakin dibutuhkan kemampuan seseorang dalam berpikir kreatif yang diharapkan mampu memberikan sumbangan bermakna kepada ilmu pengetahuan, teknologi, kesenian serta kepada kesejahteraan bangsa pada umumnya (Munandar, 1999:12). Itulah beberapa alasan bahwa kemampuan berpikir kreatif sangat penting untuk dirangsang, dipupuk, dan dikembangkan sejak dini.

Evans (dalam Siswono, 2008:14) menyatakan bahwa, kemampuan berpikir kreatif adalah kemampuan mental yang digunakan seseorang untuk membangun ide atau gagasan baru. Setiap siswa memiliki kemampuan tersebut, namun tingkatannya berbeda-beda antara siswa yang satu dengan siswa yang lain. Dengan demikian, diperlukan suatu patokan atau kriteria tingkat berpikir kreatif yang valid. Siswono (2007:2) menjelaskan bahwa, kriteria tingkat berpikir kreatif berguna sebagai pembanding atau acuan untuk mengetahui letak kelemahan siswa dan cara mengatasi kelemahan itu. Di samping itu, tingkat kemampuan berpikir kreatif siswa dapat digunakan sebagai petunjuk mengetahui kualitas kemampuan siswa dalam berpikir kreatif dan perkembangannya selama proses pembelajaran.

Munandar (1977:229) mengemukakan bahwa kreativitas merupakan konstruk multidimensional yang dapat ditinjau dari dimensi kognitif, afektif, dan psikomotor. Oleh karena itu, kemampuan berpikir kreatif dapat diukur melalui beberapa pendekatan. Selain itu, alat yang digunakan untuk mengukur juga ada beragam jenisnya yaitu pengukuran langsung, pengukuran tidak langsung, pengukuran dengan unsur-unsur yang menandai ciri tersebut, pengukuran ciri kepribadian yang berkaitan erat dengan bagian tersebut, dan beberapa jenis pengukuran yang berupa nontes. Di antara jenis tes tersebut, tes yang dapat digunakan untuk mengukur kemampuan berpikir kreatif di bidang bahasa Indonesia adalah pengukuran dengan unsur-unsur kemampuan berpikir kreatif. Unsur-unsur yang menandai ciriciri kemampuan berpikir kreatif meliputi kelancaran, keluwesan, dan keaslian. Adapun tes yang dapat digunakan untuk mengukur hal tersebut ialah melalui tes menulis cerita.

Salah satu materi pembelajaran menulis yang harus dipelajari dan dikuasai siswa sekolah dasar adalah menulis naratif. Siswa dapat mengungkapkan ide kreatifnya kepada orang lain melalui kegiatan menulis naratif. Dalam kurikulum 2013, kompetensi inti yang harus dikuasai siswa kelas V semester 2 yaitu, "Menyajikan pengetahuan faktual dan konseptual dalam bahasa yang jelas, sistematis, logis, dan kritis, dalam karya yang estetis, dalam gerakan yang mencerminkan anak sehat, dan dalam tindakan yang mencerminkan perilaku anak beriman dan berakhlak mulia", dengan salah satu kompetensi dasar, "Mengolah dan menyajikan teks cerita naratif sejarah tentang nilai-nilai perkembangan kerajaan Islam di Indonesia secara mandiri dalam bahasa Indonesia lisan dan tulis dengan memilih dan memilah kosakata baku" (Permendikbud, 2013:81).

Berdasarkan uraian tersebut, maka dilakukan observasi pembelajaran bahasa Indonesia pada siswa kelas $\mathrm{V}$ di beberapa sekolah dasar negeri di Kecamatan Gayungan Surabaya yang difokuskan pada materi menulis naratif. Sekolah yang diobservasi yaitu SDN Ketintang I/ 409 Surabaya, SDN Gayungan II/ 423 Surabaya, dan SDN Dukuh Menanggal I/ 424 Surabaya. Peneliti melakukan wawancara dengan guru kelas $\mathrm{V}$ dari masingmasing sekolah tersebut. Dari kegiatan wawancara diperoleh informasi bahwa secara keseluruhan keterampilan siswa kelas $\mathrm{V}$ dalam menulis naratif sudah cukup baik. Siswa sudah mampu menulis naratif dengan tema yang ditentukan oleh guru. Siswa sudah mampu menggunakan pilihan kata yang tepat, walaupun kadang masih ada beberapa siswa yang mencampur dengan bahasa daerah. Siswa sudah mampu menulis dengan ejaan yang tepat, namun penggunaan tanda baca masih perlu diperbaiki lagi. Pada intinya siswa telah mampu menulis naratif walaupun hasilnya tidak terlalu baik juga tidak jelek. 
Selanjutnya dilakukan pengamatan terhadap pelaksanaan pembelajaran menulis naratif di kelas $\mathrm{V}$ pada ketiga sekolah tersebut. Hasil kegiatan pengamatan tersebut, menunjukkan bahwa guru kelas V pada masing-masing sekolah telah melaksanakan pembelajaran menulis dengan baik. Guru dapat memberikan bimbingan pada setiap tahap, mulai dari tahap pramenulis, penulisan, dan pascamenulis. Hasil karangan siswa tersebut akhirnya dikumpulkan dan dinilai oleh guru. Penilaian guru terhadap hasil karangan siswa meliputi kesesuaian isi dengan tema, ketepatan ejaan, dan ketepatan diksi. Dari hasil penilaian itu, tidak dideskripsikan bagaimana dan sejauh mana kemampuan berpikir kreatif siswa dalam menulis karangan tersebut. Jadi, kemampuan berpikir kreatif siswa dalam menulis karangan belum bisa diketahui secara pasti.

Berdasarkan uraian di atas peneliti tertarik untuk melakukan penelitian yang bertujuan untuk menganalisis kemampuan berpikir kreatif pada siswa kelas V SD. Penelitian ini difokuskan pada kemampuan berpikir kreatif siswa dalam menulis naratif. Atas dasar itulah peneliti menentukan judul penelitian "Kemampuan Berpikir Kreatif dalam Menulis Naratif Siswa Kelas V Sekolah Dasar Negeri di Kecamatan Gayungan Surabaya”.

\section{METODE}

Penelitian ini bermaksud memperoleh deskripsi terperinci tentang kemampuan berpikir kreatif yang muncul dari sampel penelitian. Deskripsi terperinci mengenai kemampuan berpikir kreatif sampel penelitian diperoleh dari tes menulis naratif. Hasil tes menulis naratif tersebut dianalisis berdasarkan indikator kemampuan berpikir kreatif yang meliputi kelancaran, keluwesan, dan keaslian. Oleh karena itu, jenis penelitian ini adalah penelitian deskriptif. Adapun pendekatan yang digunakan adalah pendekatan kuantitatif dengan data utama yang berupa hasil tes tertulis.

Variabel dalam penelitian ini adalah kemampuan berpikir kreatif. Variabel tersebut dibagi menjadi tiga subvariabel yaitu kelancaran (fluensi), keluwesan (fleksibilitas), dan keaslian (orisinalitas) yang diidentifikasi dari hasil tes menulis naratif sampel penelitian.

Populasi penelitian ini adalah seluruh siswa kelas V sekolah dasar negeri tahun pelajaran 2014/2015 di Kecamatan Gayungan Surabaya. Kecamatan Gayungan merupakan salah satu kecamatan yang berada di Surabaya, tepatnya di Surabaya bagian selatan. Kecamatan Gayungan terdiri atas empat kelurahan yaitu kelurahan Ketintang, Kelurahan Dukuh Menanggal, Kelurahan Menanggal, dan Kelurahan Gayungan. Sekolah dasar negeri yang ada di Kecamatan Gayungan Surabaya keseluruhan berjumlah 13 sekolah.

Teknik pengambilan sampel dalam penelitian ini yakni purposive sampling. Teknik pengambilan sampel ini berorientasi terhadap pemilihan sampel pada populasi dengan tujuan yang spesifik. Dalam hal ini peneliti memilih 3 sekolah untuk mewakili 13 sekolah yang ada di Kecamatan Gayungan untuk dijadikan sebagai sampel dalam penelitian ini. Sekolah dasar negeri yang dipilih adalah sekolah yang memiliki kualitas yang hampir sama yaitu memiliki akreditasi B. Artinya sekolah yang dipilih adalah sekolah yang berkualitas menengah, bukan sekolah terbaik tetapi juga bukan yang terjelek. Alasan kedua adalah adanya prestasi-prestasi di bidang menulis yang pernah diraih siswa di sekolah tersebut. Selain itu, kelas yang dipilih didasarkan pada jumlah siswa yang hampir sama.

Berdasarkan kriteria tersebut, sampel penelitian ini adalah siswa kelas V SDN Ketintang I/ 409 Surabaya yang berjumlah 34 siswa, SDN Gayungan II/ 423 Surabaya yang berjumlah 31 siswa, dan SDN Dukuh Menanggal I/ 424 yang berjumlah 32 siswa. Jadi, jumlah keseluruhan sampel dalam penelitian ini adalah 97 siswa kelas $\mathrm{V}$ yang dijadikan sampel penelitian.

penelitian ini dilakukan dalam tiga tahap kegiatan pokok yaitu tahap persiapan, tahap pengumpulan data, dan tahap analisis data serta penyusunan laporan. Kegiatan pokok yang dilakukan pada tahap persiapan adalah mengkaji literatur yang terkait dengan penelitian dan mempersiapkan instrumen penelitian. Adapun langkah-langkah yang dilakukan oleh peneliti adalah membuat instrumen penelitian yang meliputi lembar tes menulis naratif dan lembar validasi lembar tes menulis naratif. Kemudian validasi instrumen dan perbaikannya.

Langkah yang dilakukan pada tahap pengumpulan data adalah melaksanakan tes menulis naratif pada siswa kelas $\mathrm{V}$ pada masing-masing SD yang dipilih menjadi sampel penelitian. Tes menulis naratif dilaksanakan dalam satu pertemuan dengan alokasi waktu 80 menit. Pengumpulan data dilaksanakan di SDN Ketintang I/409 Surabaya pada 8 Juni 2015, di SDN Gayungan II/423 Surabaya pada 8 Juni 2015, 
dan di SDN Dukuh Menanggal/424 Surabaya pada 9 Juni 2015.

Adapun langkah-langkah yang akan dilakukan pada tahap terakhir adalah analisis data yang telah didapatkan pada tahap kedua. Selanjutnya pembahasan hasil penelitian akan dilakukan denganmenafsirkan hasil analisis data kemudian menarik simpulan.

Tenik pengumpulan data merupakan langkah utama dalam penelitian, karena tujuan utama dalam penelitian ini adalah mengumpulkan data. pengumpulan data dalam penelitian ini dilakukan melalui teknik tes. Tes yang digunakan dalam penelitian ini adalah tes tertulis. teknik tes pada penelitian ini digunakan untuk memperoleh data hasil menulis naratif siswa. Adapun aspek yang dinilai dari hasil tes menulis naratif meliputi aspek kelancaran (fluensi), keluwesan (fleksibilitas), dan keaslian (orisinalitas). Berdasarkan hasil tes menulis naratif tersebut, siswa dikelompokkan menjadi lima tingkatan yaitu sangat kreatif, kreatif, cukup kreatif, kurang kreatif, dan tidak kreatif. Dengan demikian, dapat diketahui kemampuan berpikir kreatif siswa dalam menulis naratif.

Instrumen utama penelitian ini adalah peneliti. Menurut Sugiyono (2008), kedudukan peneliti sebagai instrumen (human instrument) berfungsi untuk menetapkan fokus penelitian, memilih sampel penelitian, melakukan pengumpulan data, menganalisis data, dan membuat simpulan. Prinsip dasar yang harus ditaati oleh peneliti sebagai instrumen adalah peneliti harus bersifat netral dan objektif. Tahap pengambilan data dilakukan peneliti dengan menggunakan instrumen pendukung berupa lembar tes dan lembar validasi lembar tes.

Lembar tes yang digunakan dalam penelitian ini memuat soal menulis naratif serta petunjuk cara mengerjakannya. Tes ini dilakukan dengan tujuan untuk mengtahui kemampuan berpikir kreatif siswa dalam menulis naratif. Jenis tes yang diberikan kepada siswa adalah tes tertulis dengan bentuk tes uraian. Soal menulis naratif tersebut dibuat berdasarkan tujuan pembelajaran yang sesuai dengan kompetensi inti dan kompetensi dasar bahasa Indonesia kelas V, yaitu menulis naratif tentang pahlawan. Siswa diberikan tiga pilihan topik yang ditentukan oleh peneliti. Siswa diminta untuk menulis karangan dengan memilih salah satu di antara tiga topik antara lain pahlawan favoritku, pengalamanku menjadi seorang pahlawan, atau jika aku menjadi pahlawan aku ingin menjadi seperti(...).

Lembar validasi lembar tes digunakan sebagai acuan untuk menilai kelayakan lembar tes menulis naratif yang digunakan untuk mengukur kemampuan berpikir kreatif siswa. Instrumen ini digunakan untuk mengevaluasi lembar tes dari aspek format, isi, dan bahasa. Penilaian ini dilakukan oleh pakar yang memberi keputusan tentang kualitas lembar tes menulis naratif yang akan diberikan pada siswa. Selain itu, masukan dari validator dijadikan dasar melakukan revisi lembar tes menulis naratif sebelum digunakan. Lembar validasi lembar tes menulis naratif ini divalidasi oleh dua orang validator. Validator pertama adalah Dr. Suharmono Kasiyun, M.Pd., dosen S1 Pendidikan Bahasa dan Sastra Indonesia Universitas Negeri Surabaya. Validator kedua adalah Dr. Subardi Agan, M.Pd., dosen S1 Pendidikan Bahasa dan Sastra Indonesia Universitas Nusantara PGRI Kediri.

Berdasarkan data hasil validasi rata-rata totalnya adalah 3.7 dan persentase kelayakan lembar tes menulis naratif adalah 92.7\%. Hasil tersebut dapat dikategorikan sangat baik, sehingga draf 2 dinyatakan dapat digunakan tanpa revisi. Berdasarkan skor tersebut maka komponen kelayakan lembar tes menulis naratif dinyatakan sangat berkualitas dan layak digunakan.

Penilaian kemampuan berpikir kreatif dalam menulis naratif siswa mengacu pada tiga indikator yaitu kelancaran (fluensi), keluwesan (fleksibilitas), dan keaslian (orisinalitas). Data ini dianalisis dengan deskriptif kuantitatif oleh dua penilai. Penilai pertama adalah peneliti dan penilai kedua adalah Daniar Meiliana, S.Pd. guru kelas V SDN Dukuh Menanggal I/ 424 Surabaya.

Berikut rubrik dan deskriptor penilaian kemampuan berpikir kreatif siswa dalam menulis naratif yang digunakan sebagai pedoman penilaian.

Tabel 1. Rubrik Penilaian Kemampuan Berpikir Kreatif Siswa dalam Menulis Naratif

\begin{tabular}{|c|c|c|c|c|c|c|}
\hline \multirow{2}{*}{ No. } & \multirow{2}{*}{ Aspek yang Dinilai } & \multicolumn{5}{|c|}{ Skor } \\
\hline & & 1 & 2 & 3 & 4 & 5 \\
\hline 1. & Kelancaran (fluensi) & & & & & \\
\hline 2. & Keluwesan (fleksibilitas) & & & & & \\
\hline 3. & $\begin{array}{l}\text { Keaslian (orisinalitas) } \\
\text { Jumlah Skor }\end{array}$ & & & & & \\
\hline
\end{tabular}

(Diadaptasi dari Munandar 1999) 
Tabel 2. Deskriptor Penilaian Kemampuan Berpikir Kreatif Siswa dalam Menulis Naratif

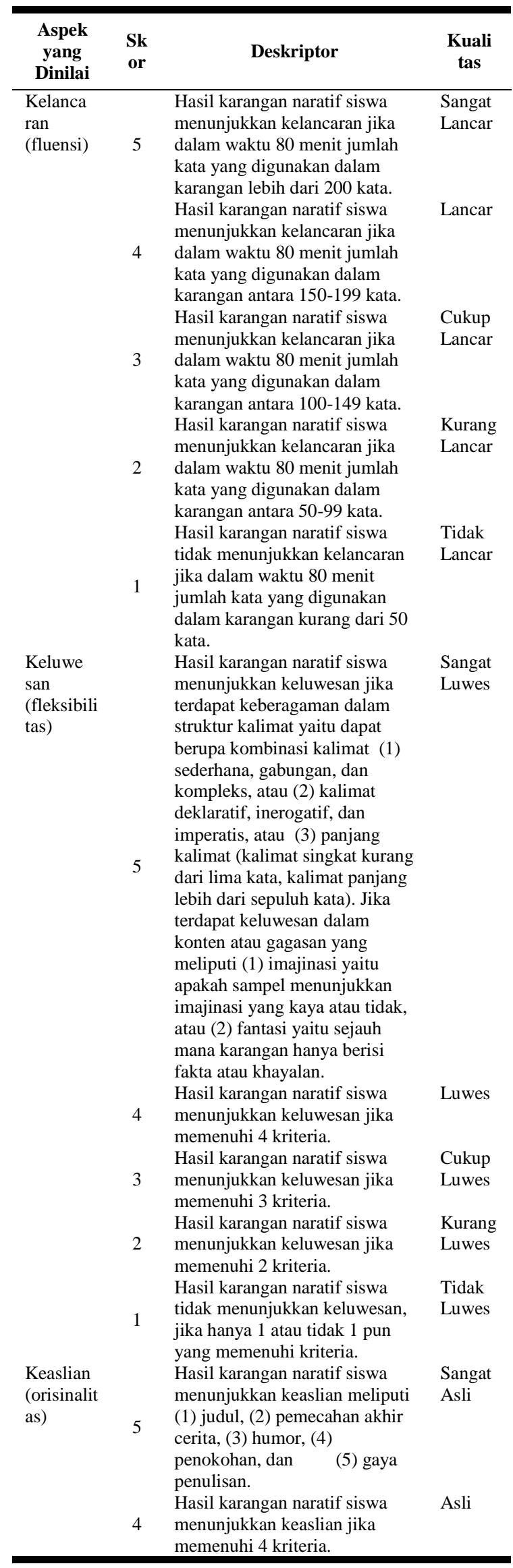

\begin{tabular}{|c|c|c|}
\hline 3 & $\begin{array}{l}\text { Hasil karangan naratif siswa } \\
\text { menunjukkan keaslian jika } \\
\text { memenuhi } 3 \text { kriteria. }\end{array}$ & $\begin{array}{l}\text { Cukup } \\
\text { Asli }\end{array}$ \\
\hline 2 & $\begin{array}{l}\text { Hasil karangan naratif siswa } \\
\text { menunjukkan keaslian jika } \\
\text { memenuhi } 2 \text { kriteria. }\end{array}$ & $\begin{array}{l}\text { Kurang } \\
\text { Asli }\end{array}$ \\
\hline 1 & $\begin{array}{l}\text { Hasil karangan naratif siswa } \\
\text { tidak menunjukkan keaslian } \\
\text { jika hanya } 1 \text { atau tidak } 1 \text { pun } \\
\text { memenuhi kriteria. }\end{array}$ & $\begin{array}{l}\text { Tidak } \\
\text { Asli }\end{array}$ \\
\hline
\end{tabular}

(Diadaptasi dari Munandar, 1999:43)

Mengacu pada deskriptor penilaian kemampuan berpikir kreatif dalam menulis naratif tersebut, dapat diketahui bahwa setiap indikator teriri atas lima komponen. Dengan demikian, ada 15 butir yang dinilai. Setiap butir yang memenuhi syarat diberi skor 1 , sehingga skor tertinggi yang dapat diperoleh siswa pada masing-masing indikator adalah 5. Jadi, jumlah skor tertinggi yang dapat diperoleh siswa adalah 15. Adapun skor minimal yang harus diperoleh siswa pada masingmasing indikator adalah 3 dengan kualitas "cukup". Dengan demikian, siswa dapat dinyatakan memenuhi indikator kemampuan berpikir kreatif apabila masing-masing indikator memperoleh skor $\geq 3$. Setelah dinilai hasil karangan naratif siswa dibandingkan satu sama lain. Khusus pada indikator keaslian apabila kelima komponen terpenuhi tetapi sama persis dengan karangan siswa yang lain, maka skor yang diperoleh dikurangi 1. Semakin ditemukan banyak kemiripan, semakin berkurang skor keaslian.

Berdasarkan perolehan skor pada tiap-tiap indikator, maka dapat ditentukan tingkat kemampuan berpikir kreatif siswa dalam menulis naratif. Adapun kriteria penjenjangan tingkat berpikir kreatif siswa dalam menulis naratif ditunjukkan dalam tabel berikut.

Tabel 3 . Tingkat Kemampuan Berpikir Kreatif Siswa dalam Menulis Naratif

\begin{tabular}{ll}
\multicolumn{1}{c}{ Tingkat } & \multicolumn{1}{c}{ Karakteristik } \\
\hline Tingkat 4 & Jika siswa mampu menunjukkan \\
(Sangat & $\begin{array}{l}\text { kelancaran, keluwesan, dan keaslian, } \\
\text { atau keaslian dan keluwesan dalam } \\
\text { Kreatif) }\end{array}$ \\
menulis naratif. \\
Tingkat 3 & Jika siswa mampu menunjukkan \\
(Kreatif) & kelancaran, keluwesan, atau kelancaran \\
& dan keaslian dalam menulis naratif. \\
Tingkat 2 & Jika siswa mampu menunjukkan \\
(Cukup & keluwesan atau keaslian dalam menulis \\
Kreatif) & naratif. \\
Tingkat 1 & Jika siswa mampu menunjukkan \\
(Kurang & kelancaran dalam menulis naratif. \\
Kreatif) & \\
Tingkat 0 & Jika siswa tidak mampu menunjukkan \\
(Tidak & ketiga aspek indikator berpikir kreaif \\
Kreatif) & menulis naratif.
\end{tabular}

(Diadaptasi dari Siswono, 2008:23) 


\section{HASIL DAN PEMBAHASAN}

Hasil penelitian yang dilakukan pada siswa kelas V SDN di Kecamatan Gaungan Surabaya menunjukkan bahwa ada $6 \%$ atau 6 siswa dikategorikan sangat kreatif (TKBK 4), 45\% atau 44 siswa dikategorikan kreatif (TKBK 3 ), $4 \%$ atau 4 siswa dkategorikan cukup kreatif (TKBK 2), 21\%atau 20 siswa dikategorikan kurang kreatif (TKBK 1), dan $13 \%$ atau 13 siswa dikategorikan tidak kreatif (TKBK 0). Jika dijumlah, secara keseluruhan ada 56\% atau 54 dari 97 siswa dijadikan sampel penelitian dapat dinyatakan memiliki kemampuan berpikir kreatif dalam menulis naratif. Hasil tersebut menunjukkan bahwa kemampuan berpikir kreatif dalam menulis naratif sebagian besar siswa kelas V SDN di Kecamatan Gayungan Surabaya cenderung berada di TKBK 3 atau tingkat kreatif. Hanya sedikit siswa yang yang dapat dikategorikan sangat kreatif (TKBK 4).

Berdasarkan data hasil kelancaran berpikir siswa kelas V SDN di Kecamatan Gayungan Surabaya dapat diketahui bahwa dari 97 siswa 81 diantaranya sudah memenuhi indikator kelancaran berpikir dalam menulis naratif dan hanya 16 siswa yang belum dapat dinyatakan memenuhi indikator tersebut. Hasil ini menunjukkan bahwa tingkat ketercapaian indikator kelancaran berpikir siswa kelas V SDN di Kecamatan Gayungan Surabaya sangat tinggi.

Data hasil keluwesan berpikir dalam menulis naratif siswa kelas V SDN di Kecamatan Gayungan Surabaya menunjukkan bahwa sebanyak 56 siswa dapat dinyatakan memenuhi indikator, sedangkan 41 siswa lainnya belum memenuhi indikator keluwesan. Hasil ini menunjukkan bahwa tingkat ketercapaian indikator keluwesan siswa cukup tinggi.

Jika ditinjau dari masing-masing komponen secara rinci 93 siswa telah menggunakan keberagaman bentuk kalimat dalam karangannya. Ada 26 siswa yang menggunakan keberagaman penggunaan kalimat dalam karangannya. Ada 81 siswa yang menggunakan keberagaman panjang kalimat dalam karangannya. Ada 42 siswa yang menggunakan imajinasi yang kaya dalam karangannya. Hanya 18 siswa yang menggunakan unsur fantasi dalam karangannya. Berdasarkan data ini, dapat disimpulkan bahwa pada aspek keluwesan dalam struktur kalimat sebagian besar siswa lebih memilih menggunakan keberagaman dalam bentuk kalimat dan panjang kalimat. Hanya sedikit siswa yang menggunakan keberagaman dalam penggunaan kalimat. Pada aspek keluwesan konten dan gagasan, hampir separuh siswa telah mampu menunjukkan imajinasi yang kaya dalam karangannya. Hanya sedikit siswa yang menggunakan unsur fantasi dalam karangannya.

Data hasil keaslian berpikir dalam menulis naratif siswa kelas V SDN di Kecamatan Gayungan Surabaya menunjukkan bahwa hanya 6 siswa yangdapat dinyatakan memenuhi indikator tersebut. Hasil ini menunjukkan bahwa tingkat ketercapaian indikator ini sangat rendah.

Jika ditinjau dari masing-masing komponen indikator keaslian secara rinci ada 30 siswa yang memenuhi komponen keaslian dalam judul karangan. Ada 9 siswa yang memenuhi komponen keaslian dalam pemecahan akhir cerita. Ada 15 siswa yang memenuhi komponen penggunaan humor dalam karangan. Ada 19 siswa yang memenuhi komponen penggunaan nama atau kata baru dalam karangan. Ada 13 siswa yang memenuhi komponen keaslian dalam penggunaan gaya penulisan. Berdasarkan data ini, dapat disimpulkan bahwa kemampuan siswa dalam memenuhi indikator keaslian berpikir masih kurang di setiap komponen.

Apabila diurutkan berdasarkan jumlah siswa yang dapat memenuhi kriteria ketiga indikator kemampuan berpikir kreatif dalam menulis naratif, maka indikator kelancaran menempati posisi pertama, karena sebagian besar siswa dapat dinyatakan memenuhi indikator ini. Urutan berikutnya adalah indikator keluwesan. Urutan terakhir adalah indikator keaslian, karena sangat sedikit siswa yang dapat dinyatakan memenuhi indikator ini.

Berdasarkan hasil rekapitulasi kelancaran berpikir dalam menulis naratif siswa kelas V SDN di Kecamatan Gayungan Surabaya dapat diketahui bahwa 81 siswa dari 97 siswa yang dijadikan sampel penelitian telah memenuhi indikator kelancaran berpikir dalam menulis naratif.

Kelancaran berpikir adalah indikator kemampuan berpikir kreatif yang paling mudah untuk diidentifikasi dari karangan siswa, karena dapat dievaluasi berdasarkan jumlah kata yang digunakan dalam karangan. Adapun kriteria yang harus dipenuhi agar dapat dinyatakan memenuhi indikator kelancaran yaitu siswa harus dapat menghasilkan $\geq 100$ kata dalam menulis karangan naratif dalam waktu 80 menit. Merujuk pada hasil analisis kelancaran berpikir, dapat disimpulkan bahwa hanya sedikit siswa yang tidak dapat 
menghasilkan $\geq 100$ kata dalam waktu 80 menit. Hal ini menunjukkan bahwa siswa kelas $\mathrm{V}$ telah mampu menuangkan pikiran, perasaan, dan gagasannya menggunakan bahasa tertulis dengan lancar. Hasil ini jika dinilai dari sudut pandang teori Bruner (dalam Suyono dan Hariyanto, 2011:89) dapat disimpulkan bahwa siswa kelas $\mathrm{V}$ lebih condong pada aspek simbolik. Artinya siswa kelas V sudahmampu menggambarkan kapasitas berpikir melalui simbol-simbol bahasa.

Berdasarkan hasil rekapitulasi keluwesan berpikir dalam menulis naratif siswa kelas V SDN di Kecamatan Gayungan Surabaya dapat diketahui bahwa 56 dari 97 siswa yang dijadikan sampel penelitian telah memenuhi indikator keluwesan berpikir dalam menulis naratif.

Keluwesan berpikir dalam menulis naratif pada penelitian ini meliputi keluwesan dalam struktur kalimat dan keluwesan dalam konten dan gagasan. Keluwesan dalam struktur kalimat ditinjau berdasarkan keragaman bentuk kalimat, keragaman penggunaan kalimat, dan keragaman dalam panjang kalimat yang digunakan dalam karangan naratif siswa. Adapun keluwesan dalam konten dan gagasan meliputi penggunaan imajinasi dan fantasi siswa dalam karangan. Siswa harus memenuhi setidaknya tiga dari lima kriteria keluwesan tersebut agar dapat dinyatakan memenuhi indikator keluwesan dalam menulis naratif.

Secara rinci, ada 93 siswa yang menggunakan keberagaman bentuk kalimat dalam karangannya. Ada 26 siswa yang menggunakan keberagaman penggunaan kalimat dalam karangannya. Ada 81 siswa yang menggunakan keberagaman panjang kalimat dalam karangannya. Ada 52 siswa yang menggunakan imajinasi dalam karangannya. Ada 18 yang menggunakan fantasi dalam karangannya. Dengan demikian, dapat disimpulkan bahwa kriteria keluwesan berpikir dalam menulis naratif yang paling banyak dipenuhi oleh siswa adalah keberagaman dalam bentuk kalimat, terbanyak selanjutnya adalah keberagaman dalam panjang kalimat, lalu keluwesan dalam penggunaan imajinasi. Sebagian besar siswa memilih menulis cerita fakta daripada cerita fantasi. Apabila ditinjau dari banyaknya siswa yang memenuhi indikator keluwesan berpikir dalam menulis naratif, dapat disimpulkan bahwa siswa kelas V SDN di Kecamatan Gayungan Surabaya telah mampu berpikir abstrak. Artinya siswa telah mampu memecahkan masalahnya berdasarkan pengalaman. Hal ini sesuai dengan teori Piaget (dalam Santrock, 2013:61) bahwa siswa kelas V berada pada tahap operasional formal.

Penilaian keluwesan berpikir dalam menulis naratif ini tergolong sulit menurut penulis, sebab tidak semua siswa menulis menggunakan EYD dengan tepat terutama dalam penggunaan tanda baca.

Berdasarkan kesulitan yang ditemui penulis, dapat disimpulkan bahwa penggunaan EYD terutama penggunaan tanda baca sangat berpengaruh terhadap penilaian keluwesan dalam struktur kalimat. Apabila ditemukan karangan seperti ini, penulis memberi tanda pada karangan tersebut hingga dapat ditentukan awal dan akhir kalimatnya. Selain itu juga perlu dibaca dengan cermat dan berulang-ulang untuk membedakan bentuk kalimat, penggunaan kalimat, dan panjang kalimat yang digunakan dalam karangan tersebut.

Berdasarkan hasil rekapitulasi keaslian berpikir dalam menulis naratif siswa kelas V SDN di Kecamatan Gayungan Surabaya dapat diketahui bahwa dari 97 siswa yang dijadikan sampel penelitian hanyai 6 siswa yang dapat dinyatakan memenuhi indikator keaslian berpikir. Hasil tersebut membuktikan bahwa keaslian berpikir belum dimiliki kebanyakan siswa kelas V SDN di Kecamatan Gayungan Surabaya.

Keaslian berpikir dalam menulis naratif pada penelitian ini ditentukan oleh pemilihan judul, pemecahan akhir cerita, adanya unsur humor, penggunaan kata atau nama baru yang ditemukan sendiri, dan gaya penulisan. Secara rinci, ada 30 karangan siswa yang memenuhi kriteria keaslian judul. Ada 9 karangan siswa menggunakan pemecahan akhir cerita yang tak terduga. Ada 15 karangan siswa yang mengandung unsur humor. Ada 19 karangan siswa yang menggunakan nama atau kata baru yang ditemukan sendiri. Ada 10 karangan siswa yang menggunakan gaya penulisan yang unik. Berdasarkan rincian tersebut, maka dapat disimpulkan bahwa keaslian berpikir merupakan indikator kemampuan berpikir kreatif yang paling sulit dikuasai siswa, karena untuk memenuhi indikator ini siswa harus memiliki wawasan dan pengalaman yang luas. Siswa dituntut untuk menghasilkan ide-ide yang asli atau tidak lazim.

\section{PENUTUP}

Berdasarkan hasil analisis data dan diskusi hasil penelitian, maka dapat disimpulkan bahwa kemampuan berpikir kreatif siswa kelas V di SDN 
Gayungan Surabaya dapat diukur melalui tes menulis naratif. Hasil penelitian menunjukkan bahwa 54 dari 97 siswa kelas V SDN di Kecamatan Gaungan Surabaya yang dijadikan sampel penelitian sudah dapat dinyatakan memiliki kemampuan berpikir kreatif dalam menulis naratif. Secara rinci ada $6 \%$ atau 6 siswa dikategorikan sangat kreatif, $45 \%$ atau 44 siswa dikategorikan kreatif, $4 \%$ atau 4 siswa dkategorikan cukup kreatif, $21 \%$ atau 20 siswa dikategorikan kurang kreatif, dan $13 \%$ atau 13 siswa dikategorikan tidak kreatif. Hasil tersebut menunjukkan bahwa kemampuan berpikir kreatif dalam menulis naratif siswa kelas $\mathrm{V}$ SDN di Kecamatan Gayungan Surabaya cenderung berada di tingkat kemampuan berpikir kreatif 3 atau tingkat kreatif.

Tingkat kemampuan berpikir kreatif dalam menulis naratif tersebut ditentukan oleh tiga indikator yang meliputi kelancaran, keluwesan, dan keaslian. Secara rinci dari 97 siswa kelas V di SDN Kecamatan Gayungan Surabaya 81 siswa diantaranya sudah memenuhi indikator kelancaran berpikir dalam menulis naratif dan hanya 16 siswa yang belum dapat dinyatakan memenuhi indikator tersebut. Siswa kelas V di SDN Kecamatan Gayungan Surabaya yang dapat dinyatakan memenuhi indikator keluwesan berpikir dalam menulis naratif sebanyak 55 siswa, sedangkan yang belum memenuhi indikator keluwesan berpikir dalam menulis naratif sebanyak 42 siswa. Adapun siswa kelas V di SDN Kecamatan Gayungan Surabaya yang sudah dapat dinyatakan memenuhi indikator keaslian hanya sebanyak 6 siswa, sedangkan yang belum memenuhi indikator tersebut sebanyak 91 siswa.

Berdasarkan hasil penelitian yang diperoleh, kemampuan berpikir kreatif siswa kelas $\mathrm{V}$ di Kecamatan Gayungan Surabaya cenderung pada tingkat 3 dan sangat lemah pada indikator keaslian. Maka disarankan kepada guru kelas untuk mengadakan pelatihan rutin terkait dengan materimateri yang menjadi kelemahan siswa. Guru juga disarankan agar menjadikan tes menulis naratif sebagai sarana untuk mengevaluasi kemampuan berpikir kreatif siswa. Hasil tes menulis naratif tersebut dapat digunakan guru sebagai acuan untuk memperbaiki kelemahan-kelemahan siswa dan mengembangkan kemampuan berpikir kreatif siswa.

Mengingat bahwa lingkungan merupakan salah satu faktor pendorong ataupun penghambat kemampuan berpikir kreatif siswa, maka sudah selayaknya pihak kepala sekolah menyediakan ruang terbuka bagi pengembangan aktivitas yang dapat merangsang dan mengembangkan kemampuan berpikir kreatif para siswa khususnya dalam menulis naratif. Selain itu, bagi peneliti lain disarankan agar dapat melakukan kajian lebih mendalam tentang kemampuan berpikir kreatif dalam menulis naratif siswa.

\section{DAFTAR PUSTAKA}

Akhadiah, Sabarti, dkk. (1993). Bahasa Indonesia 3. Jakarta: Direktorat Pendidikan dan Kebudayaan Direktorat Jenderal Pendidikan Tinggi.

Al-Ma'ruf, Ali Imron. (2012). Kajian Stilistika Prespektif Kritik Holistik. Surakarta: UPT Penerbit dan Pecetakan UNS (UNS Press).

Aminuddin. (2010). Stilistika Pengantar Memahami Bahasa dalam Karya Sastra. Jakarta: PT. Gramedia Pustaka.

Baker, Matt. Rudd, Rick. Pomeroy, Carol. (1999). Relationships Between Criticl and Creative Thinking: Journal of Southen Agricultural Education Research Volume 51. (Online)

http://pubs.aged.tamu.edu/jsaer/pdf/Vol51/51-00173.pdf Diakses pada 22 Mei 2015.

Barak, Moses. \& Doppelt, Yaron. (2000). Using Portofolio to Enhance Creative Thinking. The Journal of Teknology Studies Summer Fall 2000, Volume XXVI, Number. (Online) http://scholar.lib.vt.edu/ejournals. Diakses pada 28 Desember 2014.

Beetlestone, F. (1998). Creative children: Imaginative Teaching. Buckingham: Open University Press.

Hariyadi dan Zamzani. (1996). Peningkatan Keterampilan Berbahasa Indonesia. Yogyakarta: Departemen Pendidikan dan Kebudayaan Direktorat Jendral Pendidikan Tinggi Bagian Proyek Pengembangan Pendidikan Guru Sekolah Dasar.

Hurlock, Elizabeth B. (1999). Perkembangan Anak Jilid 2. Jakarta: Penerbit Erlangga.

Isaken, Scott G. (1995). On The Conceptual Foundation of Creative Problem Solvin. (Online) http://www.cpsb.com. Diakses pada 1 Januari 2015.

Kemendikbud. (2014). Materi Pelatihan Guru Implementasi Kurikulum 2013 Tahun 2014 untuk SD Kelas $V$. Jakarta: Badan Pengembangan Sumber Daya Manusia Pendidikan dan Kebudayaan dan 
Penjaminan Mutu Pendidikan Kementerian Pendidikan dan Kebudayaan.

Keraf, Gorys. (2010). Argumentasi dan Naratif. Jakarta: Gramedia.

Kim, Kyung Hee. (2006). Can We Trust Creativity Tests? A Review of the Torrance Tests of Creative Thinking (TTCT). (Online) http://kkim.wmwikis.net. Diakses pada 2 Pebruari 2015.

Munandar, Utami (1977). "A Study of The Relationship between Measures of Creativity Thinking and A Number of Educational Variables in Indonesian Primari and Junior Secondary School". Jakarta: Direktorat Pembinaan Penelitian dan Pengabdian pada Masyarakat.

Munandar. Utami. (1999). Pengembangan Kreativitas Anak Berbakat. Jakarta: Rineka Cipta.

National Literacy Trust. (2013). A Guide to Text Types: Narrative, Non-fiction, and Poetryi. (Online)

http://www.literacytrust.org.uk/assets/0001/6612/G uide_to_text_types_sample.pdf Diakses pada 26 Juni 2015.

Nurgiyantoro, Burhan. (2010). Penilaian Pembelajaran Bahasa Berbasis Kompetensi. Yogyakarta: BPFE-Yogyakarta.

Permendikbud Nomor 81A Tahun 2013 Tentang Implementasi Kurikulum.

Rababah, Luqman M., Mohamed, Abdul H., Jdaitawi, Malek T., \& Melhem, Nour Z. (2013). The Level of Creativity in English Writing among Jordanian Secondary School Student.

(Online) http://www.scientificjournal.org. Diakses pada 6 Januari 2015.

Rakhmat, Jalaludin. (2012). Psikologi Komunikasi. Bandung: PT. Remaja Rosdakarya.

Ratumanan dan Laurens. (2011). Penilaian Hasil Belajar pada Tingkat Satuan Pendidikan Edisi 2. Ambon: Unesa University Press.

Riduwan. (2006). Skala Pengukuran Variabelvariabel Penelitian. Bandung: Alfabeta.

Riyanto, Yatim. 2007. Penelitian Pendidikan Kualitatif dan Kuantitatif. Jakarta: Bumi Aksara.

Rofi'uddin, A. dan Zuhdi, D. (1998). Pendidikan Bahasa dan Sastra Indonesia di Kelas Tinggi. Jakarta: Direktorat Pendidikan.

Santrock, John W.. (2009). Psikologi Pendidikan: Edisi 3 Buku 1. Jakarta: Salemba Humanika.
Siswono, Tatag Y. E.. (2007). Penjenjangan Kemampuan Berpikir Kreatif dan Identifikasi Terhadap Proses Berpikir Kreatif Siswa dalam Memngajukan dan Memecahkan Masalah Matematika. Disertasi tidak diterbitkan. Surabaya: Program Studi Pendidikan Matematika Program Pascasarjana Universitas Negeri Surabaya.

Siswono, Tatag Y. E.. (2008). Model Pembelajaran Matematika Berbasis Pengajuan dan Pemecahan Masalah Matematika. Surabaya: Unesa University Press.

Slavin, Robert. E.. (2008). Psikologi Pendidikan, Teori dan Praktik: Edisi Kedelapan. Jakarta: PT. Indeks.

Sudjana. (2005). Metoda Statistika Edisi 6. Bandung: Trasito.

Sugihastuti. (2002). Teori dan Apresiasi Sastra. Jogjakarta: Pustaka Belajar.

Sugiyono. (2008). Metode Penelitian Kualitatif, Kuantitatif, dan $R \& D$. Bandung: Alfabeta.

Sukino. (2010). Menulis itu Mudah: Panduan Praktis Menjadi Penulis Handal. Yogyakarta: Pustaka Populer LKiS.

Sunito, I., Sukardjo, M., Syukur, R., \& Latifah, U. (2013) Metaphorming Beberapa Strategi Berpikir Kreatif. Jakarta: PT. Indeks.

Suparno dan Yunus, M. (2007). Keterampilan Dasar Menulis. Jakarta: Universitas Terbuka.

Suyono dan Hariyanto. (2011). Belajar dan Pembelajaran Teori dan Konsep Dasar. Bandung: PT. Remaja Rosdakarya.

Tarigan, Henry Guntur. (2008). Menulis sebagai Suatu Keterampilan Berbahasa. Bandung: Angkasa.

Temple, C., Nathan, R., Burris, N. dan Temple, F. (1988). The Beginning of Writing. Boston: Allyn and Bacon.

Toolam, Michael. (1998). Language in Literature. Great Britain: St. Martin's Press.

Yulianto, Bambang. (2008). Aspek Kebahasaan dan Pembelajarannya. Surabaya: Unesa University Press.

Warli. (2010). Profil Kreativitas Siswa yang Bergaya Kognitif Reflektif dan Siswa yang Bergaya Kognitif Impulsif dalam Memecahkan Masalah Geometri. Disertasi tidak diterbitkan. Surabaya: Program Studi Pendidikan Matematika Program Pascasarjana Universitas Negeri Surabaya. 